\title{
THE USE OF ERGOGENIC AIDS IN EASTERN EUROPE ETHICS AND ETHOS
}

\section{從道德倫理和社會文化探討}

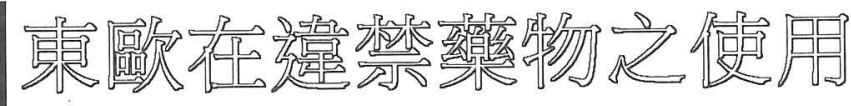

\author{
PROFESSOR J W RIORDAN \\ University of Surrey Guildford UK \\ 量奧頓教授 \\ 英國素域尼大學
}

今日國際級運動競技已變得職業化和商業化。運動員的成敗已成為大眾傳媒爭相報導的焦點。其影 響力不止於運動員本身, 也連帶牽涉國家的名聲。因此, 對運動員使用違禁藥物來增加運動表現的探討, 亦不能光從影響運動本身著手。濫用藥物, 不單止有損運動員健康, 更有違運動公平競爭的精神。為了 對抗這股歪風的泛濫, 尋根究底是需要的。鑑於使用禁藥的個案在東歐出現較多, 若能選擇這個地域的 國家, 並依循道德倫理與社會文化的途徑來進行研究, 必成一個有價值的課題。

\section{Introduction}

The use of drugs in sport cannot be examined in isolation from the general problems affecting sport. International sport has become increasingly professional, commercial and political. Both the public and the media in many countries are prepared to acclaim the successful athlete, but they are often equally ready to mock or insult a poor performance. This pressure questions the notion of top international contests being called 'sport' in the true sense of the word.

Athletes may feel forced to take drugs in order to keep up with rivals who, they believe, are taking similar drugs. The athlete may not only want to compete on a par in terms of drug use, but may even try to outstrip his/her rival in the belief that 'more is better' (Ben Johnson?). Rumours, claims and counter-claims may quickly spread to such an extent that many athletes take very large doses of drugs. While the abuse of drugs is widespread, their use is usually shrouded in secrecy. Athletes are seldom prepared to discuss the issue publicly, and the silence usually extends to coaches and doctors who administer the drugs. Yet when doping reaches the limelight as a result of a disqualification or a death, there are frequent claims that drug use among athletes in that sport is 'common knowledge'. If this is so, it is important to question why sports journalists have not spoken out or why sports officials have not introduced regular dope-testing.

In international sport, there are relentless pressures on athletes from coaches, sponsors, the public and even governments. Certain countries with social, economic or scientific achievements, or countries who want to demonstrate the superiority of their socio-political system, use sport to enhance their prestige. Sporting success can be manipulated by governments to reflect the personal characteristics of their people or the quality of their social system. So the promotion of sport has become a major political concern, and if success is believed to be possible through the use of drugs, then drugs are used. It is possible that in some countries, athletes, coaches or doctors, not believing in the ethics or benefits of doping procedures, may be forced to use them.

In December 1978, for example, the 20-year old GDR sprinter, Renate Neufield, revealed that she had regularly been forced by East German coaches to take drugs. When she refused, she claimed that she had been interrogated and threats of reprisals had been made against her and her family. She defected to the West in 1977, bringing samples of drugs which turned out to be anabolic steroids (1). 
There have been other defectors with similar stories to tell (2). As a result, the Western media have portrayed an image of Eastern European countries in which athletes perform under conditions of reprisal, and are doped physically with drugs or psychologically through hypnosis. While it is true that drugs and hypnosis have been used in Eastern Europe, the same is also true for the West. Whatever the political idealogy, the stakes in international competition are very high. Victory brings increased status for the individual, his/her family, it results in financial and career rewards and boosts the image of the nation. Defeat can result in personal humiliation, loss of career and it does nothing for the image of the athlete's nation.

The Western media have also often portrayed the communist 'preparation' of athletes as plucking potential champions from schools at an early age and awarding them various opportunities to enable them to train. But the situation is not so different in the West. Athletes may be helped through sponsorship, advertising, sports scholarships at universities, or simply given time off work and study to train. That countries then go on to flout doping regulations cannot be disputed; it is simply that in some countries it is conducted more covertly. Some have been

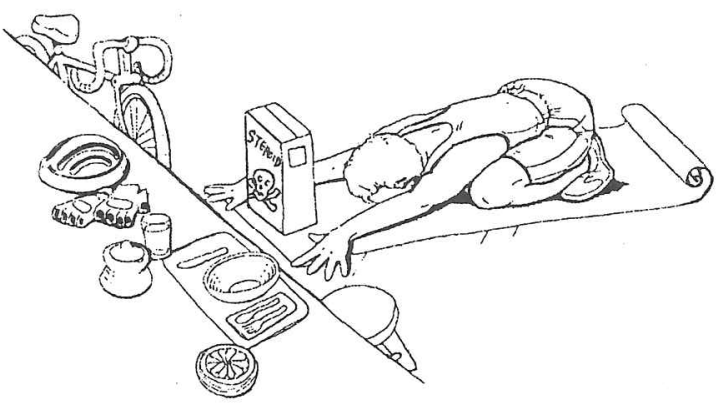
argued that drug use in Eastern Europe has been 'safer' in that it has been more controlled than in other countries where athletes rely on black market or medically unsupervised sources.

Over the past forty years Western ideas about the communist sports programme and its scientific basis have evolved in step with Cold War trends. From the start, images of the dehumanised communist athlete have served the psychological needs of populations who doubted the full humanity of all communists. At the same time, Stalinist dehumanisation throughout Eastern Europe provided a realistic basis for such images even as they were embellished by fantasies about the effects of communism on human nature.

When the gender testing of female athletes during the 1960s revealed a number of male or quasi-male imposters from Eastern Europe, Western suspicious about the essential strangeness of the denizens of Stalin's closed realm were confirmed. Yet for all the talk about the 'New Soviet Person' and the transformation of human nature, there was no indication of any extraordinary plan for the scientific development of athletes.

For a genuine understanding of drug-taking in East Europe sport, it is important not to make sweeping generalisations, nor to take a holier than thou view of the old communist system. For a start, the nine nations which made up communist Eastern Europe varied considerably not only in size (from Albania's 3m people to the USSR's 293m in 1989) and economic development (all of them, save Czechoslovakia and East Germany started their revolutions with an overwhelmingly illiterate, backward peasant population; and in 1989 the Soviet position in the world league table of per capita GNP was only 54th), but in commitment to international sporting success: for example, Albania virtually ignored it completely, while for such countries as the USSR, GDR and Romania international sport success seemed vital to their world rating or prestige. The last point also determined their attitudes towards the use of drugs: high sports success priority meant the greater likelihood of applying ergogenic 
aids. Moreover, ability to use sophisticated drugs depended on economic capacity to buy and manufacture them (and employ them without getting caught).

\section{System of sports medicine}

In Eastern Europe generally, disagreement existed for many years over what sports medicine actually constituted. The polemic was not merely academic; it reflected differences over emphasis (on elite sport or casual sport), the status of sports medical specialists and government commitment. Further, marked inter-state differences abounded; often reflecting diverse traditions, development and priorities. Let us take the two leading sports nations of Eastern Europe: the USSR and GDR.

In the USSR, the government State Committee on Science and Technology employed the term 'sports medicine' (sportivnaya meditsina) in a special resolution for the first time only in 1977, thereby signalling official approval of sports medicine as an independent discipline. Hitherto the entire area spanning sport and medicine had, since 1918, been described largely as 'medical supervision' (vrachebny kontrol) of sport and physical recreation.

We have to bear in mind that Soviet Russia had no sports science heritage to speak of and that in 1917 the Bolsheviks had taken over a semi-feudal, $80 \%$ peasant and illiterate Russian empire of over 100 nationalities, in a state of war-ruin and chaos, a land with an inclement climate, where disease, epidemics and starvation were common, and where most people had only a rudimentary knowledge of hygiene. As the first health minister put it, the country suffered from 'dreadfully backward sanitary conditions, ignorance and non-observance of rules for personal and public hygiene, leading to mass epidemics of social diseases such as syphillis, trachoma, scabies and other skin infections.' (3) He might have added cholera, leprosy, tuberculosis and smallpox; and that the average life expectancy was 32 in the Europe part of the country (4).

In the German democratic Republic, on the other hand, sports medicine inherited a long German tradition. The world's first sports college, which included a sports medical curriculum, was founded in Berlin in 1920. The world's first sports medical journal was founded in 1924 by the German Association of Physicians for the Promotion of Physical Culture. Some of the German physicians who did so much to develop modern sports medicine during the 1920s and 1930s continued to work in the GDR after 1945 (5).

State intervention into the management of East German sports medicine began as early as the first Sports Sciences Conference held in March 1952 and throughout the 1950s caused a growing rift between many sports doctors, including state institutions such as the German College of Physical Culture in Leipzig (1950), the Scientific Council for Physical Culture and Sport (1951), the State Committee for Physical Culture and Sport (1952) and, finally, the Sports Medicine Office (1953). But the government's priority in developing talented athletes to be standard-bearers for the GDR and communism ultimately prevailed, and by the early 1960s the focus of sports medicine was very definitely on discovering talent, planning individual training regimes and treating sports injuries. In fact, centres of sporting excellence (the sports boarding schools) had been set up in 1951 (just two years after the formation of the GDR), so researchers had a ready-made laboratory for tests and experiments. It was also the job of medical specialists to advise on selection of children for the special sports schools (6). 
In 1961, two important sports medical institutions came into being: the Sports Medical Institute attached to the Leipzig College, and Sports Medical Rehabilitation Centre (subsequently called the Central Institute of the Sports Medical Service) at Kreischa near Dresden. The latter was initially intended to study and improve the treatment and rehabilitation of injured and sick athletes, to accelerate their return to training and competition.

Apart from its involvement in drugs, the sports medicine systems of the USSR, GDR and some other East European states did provide a national structure of sports medicine, coordinated and funded, and run by trained sports medics responsible for the following tasks.

\section{(i) Regular monitoring of proficient athlletes}

Since athletes today are training and competing close to their limits, the risk of structural damage is much higher than it was several years ago. Stress injuries are much more commonplace now that limits once thought impossible are being reached and surpassed. So day-to-day maintenance and medical supervision of the body are essential.

\section{(ii) Regular physiological and psychological testing for establishing the effects of training}

For coaches and athletes to know when to reduce or increase training, they have to be in possession of data from regular testing not only of heart, lungs and haemoglobin level, but of changing body and blood and hormone levels.

\section{(iii) Tallent screening and forecasting}

East European practice has shown that, for this to be effective, there has to be anthropometric, physiological and psychological measurement at regular intervals: prediction of height and weight, even of muscle-leverage, leg, arm, finger-trunk ratios; early muscle biopsies to determine the balance between fast and slow twitch muscle fibres (or checking which children perform best at endurance and power events); tests for aerobic and anaerobic power, personality characteristics and so on.

\section{(iv) Coach and athlete education}

This was felt vital to prevent or anticipate injuries and break-downs, and to optimise training so that athletes can undergo intensive training for sustained periods while establishing the correct balance of suitable recuperative periods. This leads to sensible periodisation of training linked with a parallel competitive structure.

\section{(v) Team medical back-up added to a personal knowledge of athletes and a specialist sport}

The latter would mean that doctors and physiotherapists would be specialists in the problems of an individual sport (like gymnastics or athletics) or related sports, like soccer and rugby. There was also a need for regular exchange of experience both between sports and sporting nations, and between sport and related activities (eg between ballet and gymnastics or figure skating; between sport and rehabilitation of heart and blood pressure patients).

(vi) Increased attention to relatively neglected groups, like women and children

Both are groups in the population to which much more attention was paid in East Europe (and now China). With women this was most evident in the divergent success rate of female performance (7). 
These are areas that merit consideration, in which the West might from studying East European experience. However, there are other aspects of the 'sports medical system' that are not worthy of emulation and which, in any case, were mostly borrowed from the West: drugs.

\section{Drugs}

It should come as no surprise that, given the 'win at all costs' mentality that came to dominate the sports administrations in some East European countries, there had been long-term state production, testing, monitoring and administering of performance-enhancing drugs in regard to athletes as young as 7-8. It is this mendacity of the old regime-loudly condemning drug abuse in the West as a typical excess of capitalism, while concealing its own involvement in a far more extensive programme of state manufacture and distribution of drugs-from growth stimulants to growth retardants, anabolic steroids to blood doping — that has so tarnished the image of sport among many ordinary people.

When a number of emigre athletes, coaches and sports doctors had previously talked of the widespread use of drugs in sport, their testimony bore a suspicion of 'selling out'. Even when in 1989, the one-time East German ski-jump champion and later sports doctor, Hans-Georg Aschenbach, sold his story alleging that GDR athletes were 'drugged' from childhood, he was widely attacked in East and West for sensationalism. Yet the substance of what he said was never refuted. In fact, in late 1991, four one-time leading GDR swimming coaches issued a statement confessing to widespread use of anabolic steroids among GDR swimmers in the 1970s and 1980s. And a long stream of evidence has been emerging, particularly from the ex-USSR and GDR, of state-controlled administration of drugs (8).

Back in 1986, Yuri Vlasov, then Chairman of the USSR Weightlifting Federation (and the one-time world and Olympic champion, at Rome in 1960), declared that immense damage been done to Soviet sport in general, and weightlifting in particular, by the 'coach-pharmacologist' who worked alongside the sports coach. Not only did Vlasov accuse athletes of using anabolic steroids from 1968 (9), but he named names-specifically that of senior coach and USSR Sports Committee functionary Arkady Vorobyov, 'who was the first to distribute anabolic steroids to members of our national team.' (10) Vlasov had to pay for his boldness. 'The Party Central Committee instructed that no one was to publish my work; all my books were returned to me. Of course, the public was utterly unaware of what was going on.' (11)

At that time Vlasov had launched a new career as a writer of poetry and prose; he had even written a biography of his father, a Soviet spy in China whom the Soviet security forces had executed-but no one would or could publish this at the time (12). All mention of Vlasov's victory at the Rome Olympics was cut from a film of the Rome Olympics, even though Vlasov had carried the Soviet flag in the opening ceremony. He was told by Sports Minister Marat Gramov that he 'would never travel abroad again.'

What was even worse and more shameful was that his revelations about the use of anabolic steroids in weightlifting got him into trouble with international federation; that made him realise "that the entire international (weightlifting) federation was implicated'. He reported to Gramov that 'some of its leading officials were taking huge backhanders for enabling whole teams, let alone individual weightlifters, to avoid drug testing.' 
Gramov did nothing, but the international federation leaders effectively 'held a court to try me-with threats of finding our national federation several hundred thousand dollars and banning Soviet lifters from the world championships.' Vlasov concluded that as far as Soviet sports bureaucrats were concerned, 'gold medals have always been the yardstick of their work and, at the same time, a shield concealing their idleness and easy life. What was important was medals; how you got them-whether fattening up athletes on chemicals or swallowing white hot coals—was a secondary matter.' (13)

Although Vlasov and others mention the late 1960s as the arrival date of anabolic steroids in the Soviet Union, there were other drugs in use earlier. As one athlete claims, 'Steroids were preceded by psychotropic amphetamins. With my own ears in 1959 I heard our senior cycling coach, Leonid Sheleshnev, tell the sports minister Romanov that if we didn't have them we could expect no victories. Romanov replied that 'the matter would be resolved positively'; and our team received the first packet of tablets before the 1960 Games in Rome.' As a result, they were very nearly caused the death of Alexei Petrov in the $100 \mathrm{~km}$ race (in the same race as which the Danish rider Enemark-Ensen died of drug taking) (14).

It has long been known by those familiar with communist sport that drug taking was organised at the top and that no athlete was allowed overseas unless he or she had a clearance test before departing. A TV report in the Soviet Union in late 1989 revealed a document, signed in 1982 by two deputy sports ministers, prescribing anabolic steroids as part of the preparation for Soviet cross-country skiers. The document set out a programme to test the effects of steroids and for research into ways of avoiding detection (15).

At the Olympics at Montreal (1976) and Seoul (1988), it has now been revealed, the Soviet squad had a 'hospitality' boat used as a medical centre to ensure that Soviet competitors were 'clean' before competition (16). The Soviet swimming from 1973 to 1982, admitted that the use of drugs was widespread in his sport; 'From 1974, all Soviet swimmers were using banned substances. I've personally administered the drugs and advised swimmers individually on how to avoid getting caught.' He went on to indicate that while the East German method was to give drugs during periods of intensive training, which for swimmers usually comes at the start of the year, Soviet competitors took them to within a month of major meetings (17).

Following the Seoul Olympics of 1988 and the Ben Johnson drug scandal, Soviet senior athletics coach Igor Ter-Ovanesyan launched a well-publicised campaign against drug-taking in Soviet.sport. Admitting that 'many of our athletes' take drugs, he conceded that even several school athletes had been caught taking steroids; and he advised that 'society needs proper legislation to combat this evil, seriously punishing both athletes and doctors, coaches and drug-suppliers.' (18) Many subsequent reports in the press revealed cases of schoolchildren being given drugs to enhance their performance. Among those named was the coach V.Yatsyn who 'fattened up his 15year old athletes with anabolic steroids'. The exposure of several positively tested schoolchildren, it was reported, dated back to the 1984 Schoolchildren's Spartakiad (19).

The sport in which Soviet athletes won many Olympic medals is that of weightlifting; and here too the revelations mount. A journalist has written that the world champion super-heavyweight (and subsequently Soviet/ Russian team manager), Vasily Alexeyev 'took anabolic steroids. With their help he beat world records, won two Olympic and European and world championships.' (20) It was this same Alexeyev who, in 1991, when he was senior coach of the national team, called doping 'only a minor problem.' 
Other sources have uncovered drug-taking and other forms of 'doping' in cycling, rowing, body-building, gymnastics and athletics. Even after the demise of the communist system throughout Eastern Europe, as many as 44 percent of 240 Russian athletes polled in a survey called doping 'necessary or simply unavoidable' to give them a chance in international competition (21).

Such revelations and statements make it clear that post-communist sport in Eastern Europe cannot achieve any real and lasting reforms without virtually cutting itself off from global sport and its uncompromising demands for performance. In addition, the international market for athletic talent has enabled stars from many countries to become entrepreneurs who can offer themselves to meet promoters around the world. Communist incentives have been replaced by market incentives that promote doping as effectively as state Apparatchiks once did.

Finally, one must reckon with the dangerous power of sports nationalism. The nine communist states of Eastern Europe have disintegrated into as many as 25 nationalistic entities; and the number will undoubtedly increase even more. Each 'new' nation is eager to have itself put on the map and seen (with flag; anthem, logo and politicians) at international sports events in the glare of world publicity. This sort of ambition is strong today on the territory of the former Soviet Union and throughout Eastern Europe, and it will survive anti-doping reforms in other countries well into the foreseeable future.

The ethos may have changed from socialism to capitalism, but the ethics of winning international sports competitions have taken on a supranational momentum of their own. They cross national boundaries, political creeds and economic status. Sadly, it seems unlikely that doping will ever be totally eliminated from international sport; it is more likely to increase.

Modern international sports events, including the Olympic Games, induce a show of excess patriotic favour, chauvinism and even jingoism - and there are many with a vested interest in maintaining the system. Since the public seldom divorce the individual performance from the national origin of the competitor, it is hard to foresee the depolitisation of future international sport. Perhaps the time is rapidly approaching to step back and reassess what 'sport' is all about. The misuse of drugs is not only a health hazard, but is contrary to the ethics of sport and the ideals of sportsmanship and fair play. To ensure that athletes are not tempted to use drugs, they have to be convinced that dishonour is not in defeat. Otherwise, sport is in danger of becoming trials of misapplied science rather than trials of human talent and ability.

\section{NOTES}

1. See Tom Donohoe and Neil Johnson, Foul Play. Drug Abuse in Sport (Blackwell: Oxford, 1986), p 130.

2. For a number of East German (and West German) stories about doping, see Brigitte Berendonk, DopingDokumente: Von der Forschung zum Betrug (Springer Verlag: Berlin, 1991).

3. Nikolai Semashko, 'Desyatiletie sovetskoi meditsiny i fizicheskaya kultura,' Teoriya i praktika fizicheskoi kultury 5, 3, 1928.

4. Narodnoye khozyaistvo SSSR v 1962 g (Ekonomika: Moscow, 1963), p 493.

5. See John Hoberman, Mortal Engines. The Science of Performance and the Dehumanization of Sport (The Free Press: New York, 1992), pp 220-221.

6. In 1989, the GDR had twenty sports boarding schools (for a population of under $17 \mathrm{~m}$ ); the USSR had forty (for a population of $293 \mathrm{~m}$ ).

7. At the Montreal Olympics in 1976, Soviet sportswomen made up over a third (35\%) of the Soviet team (all women 
comprising $20.58 \%$ of competitors) and contributed 36 of the 125 Soviet medals (almost 30\%). GDR women comprised $40 \%$ of the GDR team and won more than half the team's gold and silver medals. By contrast, US women comprised just over a quarter (26\%) or 112 out of 425 , British and West German women slightly over a fifth $(20.6 \%$ and $21 \%$ respectively), and French women less than a fifth (18.3\%) of their teams. In the Winter Olympics of 1976, Soviet and GDR women athletes contributed more than half their teams' medals - more than double the number won by US, British, West German and French women put together. See Kurt Marker, Frau and Sport (Barth: Leipzig, 1983), pp 12-13. For the Chinese emphasis on promoting women's sport, see China Daily, 25 August 1993, p 7 ('The Chinese have a rapidly developing programme with emphasis on the women because they feel that women's records will be broken more easily'), and Telegraph Sport, 18 October 1993, p44 ('Lou Dapeng, vice-president of the Chinese athletic federation, explained that it had been policy to concentrate on women's sport'). Significantly, in 1993, Chinese women won three world titles, three world records, three junior records and set the four fastest marathons of the year. Chinese women swimmers also broke several world records. Previously, no Chinese women had set world records in either athletics or swimming.

8. For the GDR, see Alois Mader, 'Verwissenschaftlichung des Sports in der DDR—sportmedizinische Erkenntnisse und ihre Anwendung,' unpublished manuscript (Cologne 1977); A. Mader, W. Hollmann, 'Sportmedizin in der DDR,' Sportwissenschaft, No 2, June 1983, pp 152-162. Peter Kuhnst, Desmissbrauchte Sport. Die politische Instrumentalisierung des Sports in der SBZ and DDR, 1945-1957

(Verlag Wissenschaft und Politik: Koln, 1982). Renate Heinrich-Vogel, 'Mein Lebensweg vom sportbegristerten Kind zur Hochieistungssportlerin der DDR,' in Dieter Ehrich, Renate Heirich-Vogel, Gerhart Winkler, Die DDR Breiten-und Spitzensport (Kopernikus Verlag: Munich, 1981), pp 49-59.

Brigitte Berendonk, Doping-Dokumente.

9. Yuri Vlasov, 'Ya pravdu rasskazhu tebe takuyu...' Sovetsky sport, 31 October 1991, p 4.

10. Yuri Vlasov, 'Drugs and cruelty,' Moscow News, 1988, No 37, p 15; see also A. Klaz, 'Rekordy poretseptu?' Smena, 4 May 1988, p 3.

11. Vlasov, 'Ya pravdu rasskazhu tebe takuyu...'

12. 'Yuri Vlasov: pravda ob otse,' Argumenty i fakty, 1990, No 18, p 4.

13. Vlasov, 'Ya pravdu rasskazhu tebe takuyu...'

14. Stanislav Tokarev, 'Portrety na fone vremeni,' Ogonyok, 1989, No 24, p 30.

15. See Sovetsky sport, 10 October 1989, p 1.

16. Vasily Gromyko, 'Nash styd,' Leninskoye znamya, 28 March 1989, p 2.

17. Reported in Corriere Dello Sport. See Alan Page, 'Sacked Soviet official admits widescale use of drugs,' The Guardian, 2 December 1989, p 20.

18. Igor Ter-Ovanesyan, 'I declare war on anabolics,' Moscow News, 1988, No 50, p 15.

19. Ludmilla Chub, Alexander Pogonchenkov, 'Impotent po... sobstvennomu zhelaniyu,' SPID-info, November 1991, No 11, p 15.

20. Sergei Dadygin, 'Damoklov mech,' Sobesednik, April 1991, No 14, p 15.

21. See 'Es werden Wunder geschehen, 'Der Spiegel, 7 October 1991, p 258. This attitude towrads doping was evident in Hungary back in 1985 after Hungarian pharmacologist, Dr Zoltan Torma, admitted giving steroids and other banned substances to Hungarian athletes-the first East European confession of this kind from inside the country. There appeared to be 'tacit acceptance among Hungarian athletes and sports coaches that, without doping, Hungarian athletes cannot compete internationally against competitors who resort to unauthorised use of drugs.' See Vera Rich, 'Hungarian owns up,' Nature, 8 August 1988, No 316, p 479. 